\title{
Effects of continuous grazing on habitat and density of ground-foraging birds in south Texas
}

\author{
DENISE L. BAKER AND FRED S, GUTHERY
}

\section{Abotract}

We andyzed the reaponse of the key habitat features and ground-foraging birds to 2 intenatiles of continuous graing on sandy loam and clay solls in the Texns Cosutal Bend during 1984-1985. Heavy continuow grazing increased the dispersion but not necesarily the avallabllity of bare ground in compariaon with moderate continuous grazing. Responses of habltat features (structure of ground cover, key food plants) depended on soll type. Seasonal densittes of eastern meado vlarks (Stumella magna) were higher on clay than on sandy lonm solls and higher under moderate than under heavy graing. Mourning doves (Zenaida macroura) were more abundant on andy loams than on clays and more abundant under heavy than under moderate fraxing. Northern bobwhite (Colivus virginianus) abundance was uniformly low, repardles of graing intenaity and soll type.

Key Words: continuous graxing, eastern meadowlark, mourning dove, northern bobwhite, Texns

Among numerous approaches to grazing management, continuous, yearlong grazing remains one of the most common. This approach minimizes management input and may maximize livestock performance, depending on area (Holechek 1983). Further, continuous grazing has been more profitable than 4-pasture, deferred rotation and high intensity, low frequency grazing in the Texas Coastal Bend (Drawe 1988).

A primary decision in use of continuous grazing to manage wild life habitat is livestock stocking rate (AU/ha). Different stocking rates (e.g., light, moderate, heavy) have different impacts on the structure and composition of vegetation, which in turn affect the distribution and abundance of wildlife (Robinson and Bolen 1984, Ryder 1986).

Despite the prevalence of continuous grazing, little research has analyzed the impacts of different stocking rates on wildlife populations. We determined the response of key habitat features and populations of northern bobwhites (Colinus virginianus), mourning doves (Zenaida macroura), and eastern meadowlarks (Sturnella magna) to 2 intensities of continuous grazing by cattle.

\section{Study Area and Methods}

The study took place on the Rob and Bessie Welder Wildlife Refuge, San Patricio County, Texas, from July 1984 through June 1985. The refuge has 3,158 ha of rangeland and wetlands adjacent to the Aransas River (Drawe et al. 1978). Elevation ranges from 1 to $4 \mathrm{~m}$ above mean sea level. Climate ranges from humid subtropical to subhumid subtropical with average winter and summer temperatures of 13.9 and $30.0^{\circ} \mathrm{C}$, respectively (Guckian and Garcia 1979). Average annual rainfall is $89 \mathrm{~cm}$ with most occurring in late summer and fall (Drawe et al. 1978).

Data were collected on 4 experimental pastures established in

\footnotetext{
Authors are wildlife biologist, U.S. Fish and Wildlife Service, Phoenix, Arizona and research scientist, Caesar Kleberg Wild life Research Institute, Texas A\&I University, Kingsvilie. At the time of the research, the senior author was research assistant, Caesar Kleberg Wildlife Research Institute.

The Caesar Kleberg Foundation for Wildlife Conservation funded the study. Appreciation is extended to the Welder Wildlife Refuge for access and housing. This is Welder Wildlife Foundation Contribution 355

Manuscript accepted 9 May 1989.
}

1982. Soils on 2 pastures consisted mainly of Odem fine sandy loam with outcroppings of Sinton loam (Guckian and Garcia 1979). Victoria clays occurred in the other 2 pastures. A pasture on each soil type received heavy ( $2.8 \mathrm{ha} / \mathrm{AU})$ or moderate (5.6 ha/ AU) continuous grazing treatments identified as follows: $\mathrm{MS}=$ moderately grazed sandy loam soils (221 ha), HS = heavily grazed sandy loam soils $(163 \mathrm{ha}), \mathrm{MC}=$ moderately grazed clay soils (144 ha), and HC = heavily grazed clay soils (277 ha).

Eight $400-\mathrm{m}$ line transects, oriented north-south and $400 \mathrm{~m}$ apart, were established in each treated pasture by selecting a random starting point. The transects were used for seasonal sampling of vegetation structure, selected forb and grass species, and bird abundance. Sampling took place in summer (July-Aug.), autumn (Oct.-Nov.), winter (Jan.-Feb.), and spring (May-June).

We indexed vertical structure of vegetation with a profile pole (Robel et al. 1970) with readings at 13 points on each of the line transects. The first point was at the beginning of a transect and the remainder were $30.7 \mathrm{~m}$ apart. At each point we estimated percent visual obstruction (Guthery et al. 1981) for 1-dm strata on the profile pole from a distance of $4 \mathrm{~m}$ (kneeling position) up to a height of $1 \mathrm{~m}$. Seasonal sample size was 104/treated pasture except in winter 1985 when flooding prevented data collection at 7 points.

We used cluster analysis (FASTCLUS procedure, SAS 1982:433) to identify types of structural profiles of vegetation based on strata screening. Examination of the dendogram of profile types indicated observations could be classified into 2 general types: profiles with high screening below and sparse screening above $2 \mathrm{dm}$ and profiles with high screening at heights up to $1 \mathrm{~m}$ (Fig. 1). The shapes of profiles differed slightly among seasons (Baker 1988).

Because of their importance as food to the bird species under

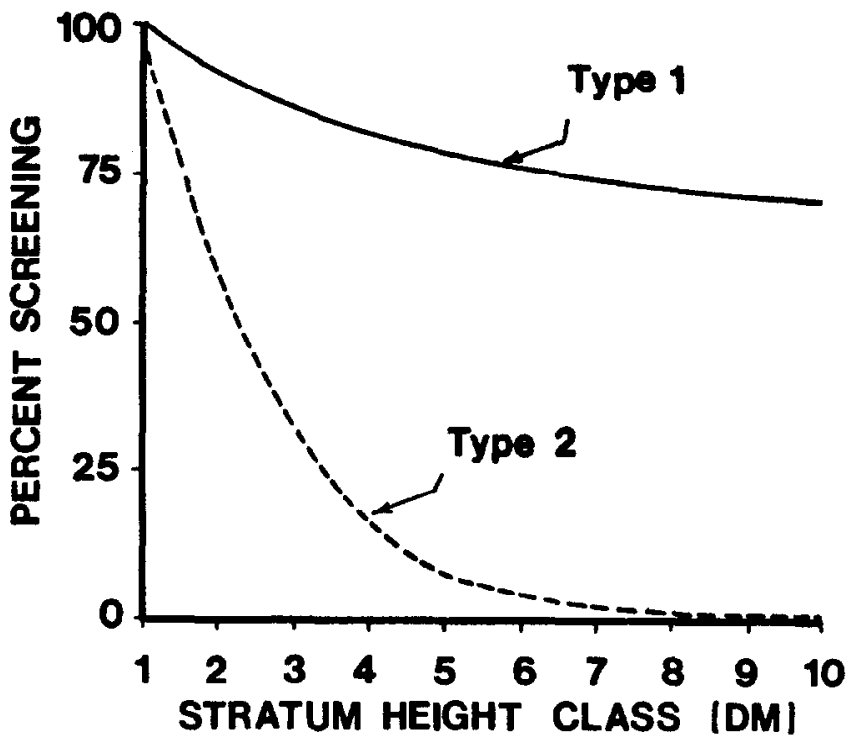

Fig. 1. Sehematic representation of vegetation profile types identified through cluater analyaia, San Patriclo County, Tezas, 1984-85. 
study (Lehmann and Ward 1941, Parmalee 1953, Gross 1958, Dillon 1961, Genung and Green 1974, Lehmann 1984, Wood 1985), we determined density, canopy coverage, and percent frequency of occurrence of the following plants on each experimental pasture: erect dayflower (Commelina erecta L.), bundleflower (Desmanthus sp.), milkpea (Galactia spp.), powderpuff (Mimosa spp.), American snoutbean [Rhynchosia americana (Mill.) Metz.], Texas croton [Croton texensis (Klotzch) Muell. Arg.], one-seed croton (C. monanthogynus Michx.), western ragweed (Ambrosia psilostachya DC.), seacoast sumpweed (Iva annua L.), bristlegrasses (Setaria spp.), paspalums (Paspalum spp.), and panic grasses (Panicum spp.). We also measured percent coverage and frequency of occurrence of bare ground and litter. Sampling consisted of 12 randomly located $0.5-\times 0.5-\mathrm{m}$ quadrats/line transect, giving 96 points/treated pasture per season. Although sampling took place in each season, we report vegetation data from summer only for economy of presentation. Baker (1988) provided data from other seasons.

Bird densities were estimated seasonally along the 8 line transects/pasture. We recorded the number of birds seen (flushed or perched) and paced the perpendicular distance to observation points during morning $(0.5$ hour before sunrise to 0900$)$ and evening ( 2 hours before sunset) walks. Each transect was walked 8 times giving a sampling effort of $25.6 \mathrm{~km} /$ treated pasture per season.

We used program TRANSECT (Burnham et al. 1980) solely to obtain an estimate of $f(0)$, the inverse of one-half the effective strip width. Small sample size precluded seasonal stratification of flushing-distance data for bobwhites. For mourning doves and meadowlarks, we stratified by winter-spring and summer-autumn periods in estimating $f(0)$. We then estimated pasture-and speciesspecific abundance as (total birds seen) (1/total distance walked) $(2 / f(0))$ and converted the estimate to number/40 ha. The Fourier series detection model adequately described $(P>0.29)$ flushing frequencies for each species. One-half effective strip widths were 8.5 \pm $0.68 \mathrm{~m}$ ( \pm se) for bobwhites, $12.9 \pm 0.70 \mathrm{~m}$ and $12.1 \pm 0.70 \mathrm{~m}$ for meadowlarks in summer-fall and autumn-winter, respectively; and $13.3 \pm 1.45 \mathrm{~m}$ and $13.3 \pm 1.24 \mathrm{~m}$ for doves in summer-fall and autumn-winter, respectively.

Although grazing and soil treatments were replicated in space, the sample size was small and potential interactions between grazing treatment and soil type could not be tested. Therefore, we stress descriptive statistics herein. In particular, we present means of seaonal samples and identify salient trends in seasonal response.

We used subsamples from within treated pastures to analyze responses of selected plant taxa and bird densities (point estimates for each replication of a transect) under a $2 \times 2$ factorial design. Because of a high frequency of zeros (non-normal distribution), data on density and coverage were rank-transformed for analysis
(Conover and Iman 1981) and retransformed for presentation. Frequency values were analyzed with the Chi-square statistic. Inferences arising form the above analyses pertain only to the study site (Hurlbert 1984).

\section{Results and Discussion}

\section{Habitat Responses}

Mean seasonal frequencies of Type 2 profiles (Fig. 1) were similar on the HS, HC, and MC pastures at $85-89 \%$ (Table 1). These frequencies were at least $23 \%$ lower $(P<0.01)$ on the MS pasture than on the other pastures. We interpret these results to indicate that grazing intensities studied had little effect on structure of ground cover on clay soils. On sandy soils, reduced grazing pressure was associated with an increase in cover available at heights $>\mathbf{2} \mathbf{d m}$.

Within seasons, grazing intensity and soil type also influenced $(P<0.05)$ the availability and dispersion of bare ground. Moderate grazing was associated with a $32 \%$ decline in the dispersion (frequency) of bare ground on both sandy loams and clays (Table 1). However, coverage by bare ground was similar on the HS and MS pastures, whereas it was $>3$ times higher on the $\mathrm{HC}$ pasture than on the $M C$ pasture. We interpret these results to indicate that higher grazing intensities will increase the dispersion, but not necessarily the availability, of bare ground, depending on soil type. Mean coverage and frequency of litter showed no large responses on any of the pastures (Table 1).

Bare ground is an important component of habitat for groundforaging, seed-eating birds such as bobwhites (Rosene 1969, Guthery 1986) and mourning doves (Rosene 1939). None of the pastures studied supplied optimum average amounts of bare ground for bobwhites, which range between 30 and $60 \%$ (Guthery 1986:115).

Four taxa showed no differences $(P>0.10)$ in density, coverage, or frequency of occurrence among experimental pastures. These species or genera were erect dayflower, bundleflower, milkpea, and powderpuff. Dayflower, bundleflower, and powderpuff were common throughout the study area; their lack of response may have been due to broad adaptability. Milkpea was seldom encountered $(0-3 \%)$ in sample plots. The lack of response simply reflected scarcity of this species.

Four species responded to soil type independent of grazing pressure and pasture interactions $(P<0.05)$ (Table 2$)$. Texas croton and American snoutbean had higher density or coverage on pastures with sandy loams than on those with clays, whereas western ragweed and seacoast sumpweed densities were higher on pastures with clays than on those with sandy loams. These results were expected based on known ecological requirements of the species (Jones 1982).

Density of one-seed croton was the only variable that showed a

Trable 1. Mean reasonal response of habitat features to heavy ( $2.8 \mathrm{ha} / \mathrm{AU}$ ) and moderate (5.6 ha/A U) continuous graxing on sandy loam and clay loama, San Patriclo County, Texas, 1984-85.

\begin{tabular}{|c|c|c|c|c|c|c|c|c|}
\hline \multirow[b]{3}{*}{ Variable } & \multicolumn{4}{|c|}{ Sandy loam } & \multicolumn{4}{|c|}{ Clay } \\
\hline & \multicolumn{2}{|c|}{ Heavy } & \multicolumn{2}{|c|}{ Moderate } & \multicolumn{2}{|c|}{ Heavy } & \multicolumn{2}{|c|}{ Moderate } \\
\hline & $\bar{x}$ & se & $\bar{x}$ & se & $\bar{x}$ & se & $\bar{x}$ & se \\
\hline $\begin{array}{l}\text { Frequency of Type } 2 \\
\text { profiles (\%) }\end{array}$ & 87 & 5.3 & 65 & 8.3 & 89 & 3.6 & 85 & 5.8 \\
\hline $\begin{array}{l}\text { Bare ground } \\
\text { Coverage (\%) } \\
\text { Frequency }(\%)\end{array}$ & $\begin{array}{l}12 \\
79\end{array}$ & $\begin{array}{l}0.2 \\
3.0\end{array}$ & $\begin{array}{l}11 \\
52\end{array}$ & $\begin{array}{l}1.6 \\
5.5\end{array}$ & $\begin{array}{l}17 \\
84\end{array}$ & $\begin{array}{l}3.3 \\
3.7\end{array}$ & $\begin{array}{c}5.1 \\
57\end{array}$ & $\begin{array}{l}0.8 \\
3.8\end{array}$ \\
\hline $\begin{array}{l}\text { Litter } \\
\text { Coverage (\%) } \\
\text { Frequency (\%) }\end{array}$ & $\begin{array}{l}33 \\
86\end{array}$ & $\begin{array}{r}11.4 \\
6.6\end{array}$ & $\begin{array}{l}31 \\
69\end{array}$ & $\begin{array}{l}11.8 \\
13.5\end{array}$ & $\begin{array}{l}32 \\
89\end{array}$ & $\begin{array}{r}12.8 \\
5.8\end{array}$ & $\begin{array}{l}38 \\
80\end{array}$ & $\begin{array}{l}18.1 \\
14.8\end{array}$ \\
\hline
\end{tabular}

isee Fig. 1. 
Table 2. Effects of experlmental pastures on the dendity $\left(n 0 . / \mathrm{m}^{2}\right)$, canopy coverage (\%), and frequency of oceurrence (\%) of seleeted wlldife food plants, San Patricio County, Texas, aummer 1984.

\begin{tabular}{|c|c|c|c|c|c|c|c|}
\hline \multirow{2}{*}{$\begin{array}{l}\text { Species } \\
\text { Variable }\end{array}$} & \multicolumn{4}{|c|}{ Pasture2 } & \multirow[b]{2}{*}{$\mathrm{MSE}^{3}$} & \multirow[b]{2}{*}{ P4 } & \multirow[b]{2}{*}{ Significant effect } \\
\hline & HS & MS & HC & MC & & & \\
\hline $\begin{array}{l}\text { American sno } \\
\text { Density } \\
\text { Cover } \\
\text { Frequency }\end{array}$ & $\begin{array}{l}0.1 \\
0.1 \\
7\end{array}$ & $\begin{array}{c}0.3 \\
0.3 \\
13\end{array}$ & $\begin{array}{l}0.0 \\
0.0 \\
0\end{array}$ & $\begin{array}{l}0.0 \\
0.0 \\
0\end{array}$ & $\begin{array}{l}36.9 \\
36.9\end{array}$ & $\begin{array}{l}0.0029 \\
0.0029 \\
0.2000\end{array}$ & $\begin{array}{l}\text { Soil } \\
\text { Soil } \\
\text { None }\end{array}$ \\
\hline $\begin{array}{l}\text { Texas croton } \\
\text { Density } \\
\text { Cover } \\
\text { Frequency }\end{array}$ & $\begin{array}{l}1.1 \\
2.3 \\
24\end{array}$ & $\begin{array}{l}0.3 \\
1.4 \\
12\end{array}$ & $\begin{array}{c}\operatorname{tr}^{5} \\
\operatorname{tr}^{5} \\
2\end{array}$ & $\begin{array}{l}\operatorname{tr} \\
\text { tr } \\
2\end{array}$ & $\begin{array}{l}51.4 \\
54.1\end{array}$ & $\begin{array}{l}0.0059 \\
0.0056 \\
0.0005\end{array}$ & $\begin{array}{l}\text { Soil } \\
\text { Interaction } \\
\text { Interaction }\end{array}$ \\
\hline $\begin{array}{l}\text { One-seed crot } \\
\text { Density } \\
\text { Cover } \\
\text { Frequency }\end{array}$ & $\begin{array}{l}0.3 \\
0.1 \\
6\end{array}$ & $\begin{array}{l}0.0 \\
0.0 \\
0\end{array}$ & $\begin{array}{c}\text { tr } \\
\text { tr } \\
3\end{array}$ & $\begin{array}{l}0.0 \\
0.0 \\
0\end{array}$ & $\begin{array}{l}35.4 \\
35.9\end{array}$ & $\begin{array}{l}0.0025 \\
0.0026 \\
0.2000\end{array}$ & $\begin{array}{l}\text { Graze } \\
\text { Graze } \\
\text { None }\end{array}$ \\
\hline $\begin{array}{l}\text { Western ragw } \\
\text { Density } \\
\text { Cover } \\
\text { Frequency }\end{array}$ & $\begin{array}{l}0.6 \\
0.6 \\
15\end{array}$ & $\begin{array}{l}0.7 \\
0.3 \\
9\end{array}$ & $\begin{array}{l}1.2 \\
0.6 \\
30\end{array}$ & $\begin{array}{r}5.2 \\
2.0 \\
41\end{array}$ & $\begin{array}{l}50.1 \\
62.7\end{array}$ & $\begin{array}{l}0.0001 \\
0.0472 \\
0.0005\end{array}$ & $\begin{array}{l}\text { Soil } \\
\text { Interaction } \\
\text { Interaction }\end{array}$ \\
\hline $\begin{array}{l}\text { Seacoast sum } \\
\text { Density } \\
\text { Cover } \\
\text { Frequency }\end{array}$ & $\begin{array}{l}0.0 \\
0.0 \\
0\end{array}$ & $\begin{array}{l}0.9 \\
0.2 \\
6\end{array}$ & $\begin{array}{l}3.1 \\
1.7 \\
23\end{array}$ & $\begin{array}{c}4.4 \\
3.3 \\
51\end{array}$ & $\begin{array}{l}41.0 \\
35.3\end{array}$ & $\begin{array}{l}0.0001 \\
0.0001 \\
0.0005\end{array}$ & $\begin{array}{l}\text { Soil } \\
\text { Soil } \\
\text { Interaction }\end{array}$ \\
\hline $\begin{array}{l}\text { Bristlegrasses } \\
\text { Density } \\
\text { Cover } \\
\text { Frequency }\end{array}$ & $\begin{array}{l}0.1 \\
0.3 \\
8\end{array}$ & $\begin{array}{l}0.1 \\
0.3 \\
5\end{array}$ & $\begin{array}{l}0.1 \\
0.2 \\
7\end{array}$ & $\begin{array}{l}0.0 \\
0.0 \\
0\end{array}$ & $\begin{array}{l}54.9 \\
55.9\end{array}$ & $\begin{array}{l}0.5249 \\
0.6233 \\
0.0250\end{array}$ & $\begin{array}{l}\text { None } \\
\text { None } \\
\text { Interaction }\end{array}$ \\
\hline $\begin{array}{l}\text { Paspalums } \\
\text { Density } \\
\text { Cover } \\
\text { Frequency }\end{array}$ & $\begin{array}{l}0.5 \\
0.9 \\
18\end{array}$ & $\begin{array}{l}0.1 \\
0.8 \\
4\end{array}$ & $\begin{array}{l}\text { tr } \\
0.1 \\
1\end{array}$ & $\begin{array}{l}0.3 \\
2.0 \\
12\end{array}$ & $\begin{array}{l}53.0 \\
63.8\end{array}$ & $\begin{array}{l}0.0020 \\
0.0227 \\
0.0005\end{array}$ & $\begin{array}{l}\text { Interaction } \\
\text { Interaction } \\
\text { Interaction }\end{array}$ \\
\hline $\begin{array}{l}\text { Panic grasses } \\
\text { Density } \\
\text { Cover } \\
\text { Frequency }\end{array}$ & $\begin{array}{l}0.5 \\
0.6 \\
18\end{array}$ & $\begin{array}{l}0.1 \\
0.1 \\
4\end{array}$ & $\begin{array}{l}0.0 \\
0.0 \\
0\end{array}$ & $\begin{array}{l}\text { tr } \\
0.6 \\
4\end{array}$ & $\begin{array}{l}47.7 \\
51.0\end{array}$ & $\begin{array}{l}0.0171 \\
0.0165 \\
0.0005\end{array}$ & $\begin{array}{l}\text { Interaction } \\
\text { Interaction } \\
\text { Interaction }\end{array}$ \\
\hline
\end{tabular}

Table includes only those plants that showed responses $(P<0.05)$ on experimental pastures. Erect dayflower, bundleflower, milkpea, and powderpuff showed no response $(P>0.10)$.

2HS = heavily grazed, sandy loam soils; MS = moderately grazed, sandy loam soils, HC = heavily grazed, clay soils; MC = moderately grazed, clay soils.

${ }^{3}$ Mean square error based on 96 plots/pasture.

"Based on $F$-test of rank-transformed data for density and coverage and chi-square test for frequency.

$s_{\text {tr }}=$ trace $(<0.05)$

significant response to grazing pressure in the absence of soil and pasture interaction effects (Table 2). This croton was more dense on the heavily grazed than on moderately grazed pastures. Heavy grazing is known to favor this species (Correll and Johnston 1970).

The most common response was a soil $\times$ grazing interaction (Table 2). For example, percent cover of western ragweed and cover and density of paspalums and panic grasses seemed to be favored by heavy grazing on sandy loams and moderate grazing on clays. Baker (1988) discussed interaction effects observed during the present study in greater detail.

The high frequency of interactions could have reflected 2 underlying mechanisms. Plant phenology may vary with soil type independent of grazing program. Phenological stages vary in palatability to livestock. Whether these 2 factors operate simultaneously or independently, they could generate interaction responses such as those observed.

Also, the interactions could reflect relative palatability of a given taxon. For example, slightly unpalatable species might be used more heavily in communities consisting largely of highly unpalatable species than in communities consisting largely of highly palatable species.

\section{Bird Responses}

The response of bobwhites to soil type and grazing pressure was variable and ambiguous. Density indices ranged from $0 / 40$ ha on the HS, HC, and MC pastures in autumn and winter to $25.9 / 40$ ha on the MS pasture in autumn. Mean seasonal densities were similar on the MS, HC, and MC pastures (Fig. 2). We interpret these results to indicate that, at the time of the study, the study area provided marginal habitat conditions for bobwhites, and the grazing pressures applied since 1982 had either uniformly depressing or neutral effects on quail. This lack of response to grazing intensity is in contrast to other studies, in which increased grazing pressure associated with short duration grazing seemed to favor quail populations or their key habitat features (Bareiss 1985, Wilkins 1987, Schulz and Guthery 1988). Quail on our study area have responded positively to grazing treatments that increased the availability of bare ground and forbs and reduced the availability of grasses (Hammerquist-Wilson and Crawford 1981). Further, sandier soils generally are more favorable for bobwhites than clayey soils (Lehmann 1984).

Abundance of meadowlarks varied seasonally due to the migratory habits of this species. Averaged over experimental pastures, density ( $x \pm \mathrm{se}, \mathrm{no} . / 40 \mathrm{ha}$ ) increased from spring $(16.7 \pm 8.86)$ to fall (47.1 \pm 14.86$)$ to winter $(78.7 \pm 39.11)$ and then declined in summer $(5.1 \pm 1.85)$. Based on mean seasonal abundance, which largely reflected fall and winter populations, meadowlarks used habitat supported by clay soils more heavily than habitat supported by sandy loam soils (Fig. 2). These soil effects were significant in summer $(P<0.0056)$ and winter $(P<0.0005)$. Mean seasonal 


\section{Literature Cited}

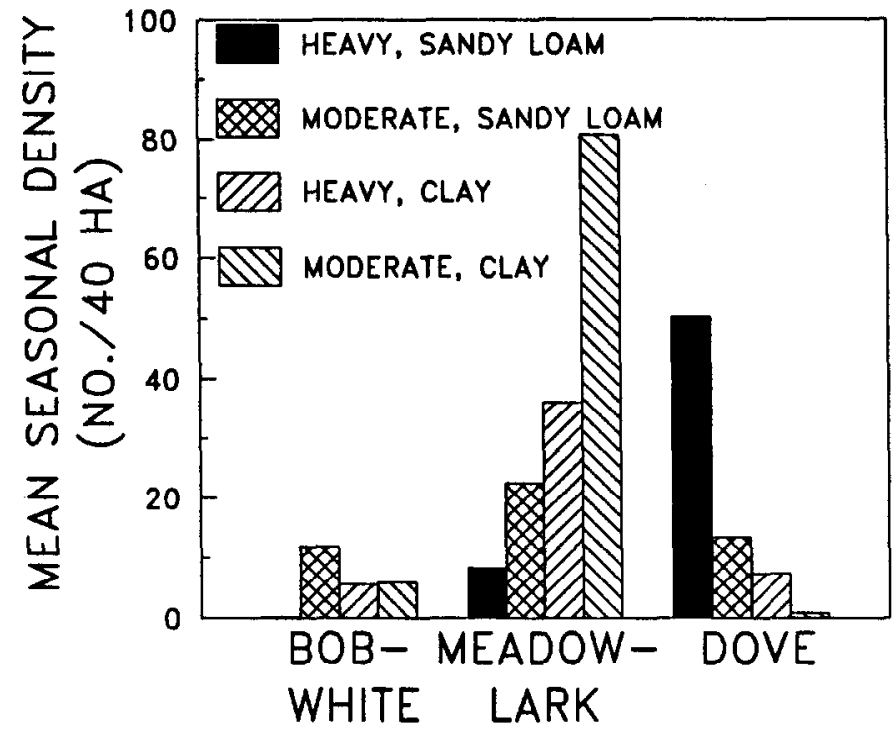

Fig. 2. Mean seasonal dendties of 3 bird species on experimental pastures differing in soll type and grazing pressure, San Patriclo County, Texas, 1984-85.

abundance was higher in moderately grazed than in heavily grazed pastures in both soil types, but effects were significant $(P<0.0063)$ only during summer. No interaction effects were observed $(P>0.05)$.

Mourning dove use of experimental pastures also reflected migratory behavior. Mean density on experimental pastures increased from summer $(4.8 \pm 1.71)$ to fall $(30.9 \pm 20.56)$, remained stable through winter (33.9 \pm 24.26$)$, and declined into spring (2.1 $\pm 0.8)$. Seasonal density averaged higher on sandy loams than on clays, and higher under heavy grazing than under moderate grazing on both soil types (Fig. 2). Soil effects were significant in autumn $(P<0.0008)$ and winter $(P<0.0279)$ and grazing effects were significant in winter $(P<0.0073)$. We attribute these responses to increased dispersion of bare ground in response to heavy grazing (Table 1), higher densities of croton, a favored food (George 1988), on sandy loams than on clays, and an apparent increase in one-seed croton due to heavy grazing (Table 2). No interaction effects were observed $(P>0.05)$.

\section{Conclusion}

We believe the most significant implication of our results is the potentially high frequency of interaction effects between grazing pressure and soil type. Because habitat management largely means management of plant taxa and communities, wildlife managers need to understand how important taxa and communities respond to grazing pressure. With such knowledge, they can make grazing management decisions consistent with goals of wildlife management. Our findings imply that the proper decision may vary according to soil type, and by extension, may be influenced by other factors that affect site productivity, such as annual precipitation and length of growing season. Whereas attention to interaction effects complicates management, it also makes possible sensitive and sophisticated management decisions. We recommend further research into the interactive effects of grazing pressure and environmental variables on wildlife habitat and populations.
Baker, D.L. 1988. Responses of bobwhites, eastern meadowlarks, mourning doves, and their habitat to two intensities of continuous grazing. M.S. thesis. Texas A\&I Univ., Kingsville.

Barelas, L.J. 1985. Response of bobwhites to short duration and continuous grazing in south Texas. M.S. thesis. Texas Tech Univ., Lubbock.

Burnham, K.P., D.R. Anderson, and J.L. Laake. 1989. Estimation of density from line transect sampling of biological populations. Wildl. Monogr. 72.

Conover, W.J., and R.L. Iman. 1981. Rank transformations as a bridge between parametric and nonparametric statistics. Amer. Stat. 35:124-129.

Correll, D.S., and M.C. Johnston. 1970. Manual of the vascular plants of Texas. Texas Res. Found. Renner, Texas.

Dillon, 0.W., Jr. 1961. Mourning dove foods in Texas during September and October. J. Wildl. Manage. 25:334-336.

Drawe, D.L. 1988. Effects of three grazing treatments on vegetation, cattle production, and wildlife on the Welder Wildlife Foundation Refuge, 1974-1982. Welder Wildl. Found. Contrib. B-8. Sinton, Texas.

Drawe, D.L., A.D. Chamrad, and T.W. Box. 1978. Plant communities of the Welder Wildlife Refuge. Welder Wildl. Found. Contrib. 5, Series B. Sinton, Texas.

Genuas, W.G., and V.E. Green, Jr. 1974. Food habitats of the meadowlark in the Everglades in relation to agriculture. Environ. Entomol. 3:39-42.

Georse, R.R. 1988. Mourning doves in Texas. Texas Parks and Wildl. Dept. Austin, Texas.

Gros, A.0. 1958. Eastern meadowlark, p. 53-80. In: A.C. Bent (Ed.). Life histories of North American blackbirds, orioles, tanagers, and allies. U.S. Nat. Mus. Bull. 211.

Guckian, W.J., and R.N. Garcin. 1979. Soil survey of San Patricio and Aransas counties, Texas. USDA, SCS. Washington, D.C.

Guthery, F.S. 1986. Beef, brush and bobwhites: quail management in cattle country. Caesar Kleberg Wildl. Res. Inst. Press. Kingsville, Texas.

Guthery, F.S., T.B. Doerr, and M.A. Taylor. 1981. Use of a profile board in sand shinnery oak communities. J. Range Manage. 34:157-158.

Hammerquist-Wilson, M.M., and J.A. Crawford. 1981. Response of bobwhites to cover changes within three grazing systems. J. Range Manage. 34:213-215.

Holechek, J.L. 1983. Considerations concerning grazing systems. Rangelands 5:208-211.

Hurlbert, S.H. 1984. Pseudoreplication in the design of ecological field experiments. Ecol. Monogr. 54:187-211.

Jones, F.B. 1982. Flora of the Texas coastal bend. Welder Wildl. Found. Contrib. B-6. Sinton, Texas.

Lehmann, V.W., and H. Ward. 1941. Some plants valuable to quail in southwestern Texas. J. Wildl. Manage. 5:131-133.

Lehmann, V.W. 1984. Bobwhites in the Rio Grande Plain of Texas. Texas A\&M Univ. Press. College Station.

Parmalee, P.W. 1953. Food and cover relationships of the bobwhite quail in east-central Texas. Ecology 34:758-770.

Robel, R.J., J.N. Briz̧s, A.D. Dayton, and L.C. Hulbert. 1970. Relationships between visual obstruction and weight of grassland vegetation. J. Range Manage. 23:295-297.

Robinson, W.L., and E.G. Bolen. 1984. Wildlife ecology and management. Macmillan Publ. Co. New York, New York.

Rosene, W., Jr. 1939. A preliminary investigation of the food habits of the mourning dove in Alabama. USDA Wildl. Res. and Manage. Leafl. 133.

Rosene, W. 1969. The bobwhite quail: its life and management. Rutgers Univ. Press. New Brunswick, New Jersey.

Ryder, R.A. 1986. Songbirds, p. 291-312. In: A.Y. Cooperrider, R.J. Boyd, and H.R. Stuart (Eds.). Inventory and monitoring of wildlife habitat. U.S. Gov. Printing Off. Washington, D.C.

SAS Inatitute, Ine. 1982. SAS user's guide: basics. SAS Inst., Inc. Cary, North Carolina.

Schula, P.A., and F.S. Guthery. 1988. Effects of short duration grazing on northern bobwhites: a pilot study. Wildl. Soc. Bull. 16:18-24.

Willins, R.N. 1987. Influence of grazing management on population attributes, habitats, and habitat selection of bobwhites in south Texas. M.S. thesis. Texas A\&M Univ., College Station.

Wood, K.N.1985. Bobwhite foods and nutrition in the Rio Grande Plain of Texas. M.S. thesis. Texas A\&I Univ., Kingsville. 